\title{
Project management in environmental construction
}

\author{
$M$ Oskolkova ${ }^{1, *}$ \\ ${ }^{1}$ Tyumen Industrial University, Volodarskogo str., 38, Tyumen, 625000, Russia
}

\begin{abstract}
The article is devoted to the analysis of the stages and tools for managing the construction project of SK Art-Sroy LLC and the development of the normal of the project planning process, the matrix of responsibility and the structure of the project team. The main activity of the organization is general contracting, management of all processes at the construction site, control of each stage of production, responsibility for implementation of the project, starting with preparation of the site and ending with the delivery of the finished object to the Customer. For clarity, the normal of one of the stages of project management is presented, with its help it is possible to trace the technologies for performing individual tasks and relationship of individual officials. The structure of the construction project team was developed and the matrix of responsibility of the project participants was determined. Also, in the course of the analysis, a number of issues were identified that the organization faces in the process of managing a construction project.
\end{abstract}

\section{Introduction}

Construction is one of the areas of activity where the use of project management tools gives the most tangible results; therefore more and more construction companies are turning their attention to project management. The success of project management depends on how much the company's employees are involved in it.

Project management is an internationally recognized methodology for business and project activities, which is purposed to optimize the time, human and financial resources, without deviating from the planned quality of the final product of the project.

Each project is unique; it has its own risks, depending on the amount of uncertainty that is present in the project. An experienced manager should always be prepared for the fact that his project will be subject to changes made under the influence of risks and uncertainties. One of the ways to solve this problem is to use modern project management tools. They allow one to achieve a high level of object quality, save resources, money, time, increase project reliability and reduce risks. Also, the use of project management tools increases the competitive advantages of the company, the efficiency of its production and economic activities and allows one to quickly respond to changing environmental conditions.

\footnotetext{
* Corresponding author: a.copytowa@yandex.ru
} 
In general, effective project management in an organization is an important task; its effectiveness needs to be improved. Competent project management in an organization is a necessary thing, therefore, it is so important to consider this topic on the example of the construction industry.

\section{Methods}

Analysis of the stages and tools for managing the construction project of SK Art-Stroy LLC showed that the construction project management at SK Art-Stroy LLC is based on the MCProject software. This program contains everything that a manager needs to effectively manage a construction project: planning, Gantt chart (timetable), analysis and resource allocation. In the program, one can make reports and calculate estimates, and it also finds and redistributes blocks overloaded with work itself.

There are two types of projects in an organization: internal and external.

Outdoor projects include objects ordered by government agencies, third-party organizations, partner organizations. Internal projects include construction objects, where the SK Art-Sroy LLC is a customer.

In this regard, the phases of the life cycle of the construction project were considered

LLC "SK Art-Stroy" (table 1): initiation, planning, implementation and completion, and management tools used to improve the effectiveness of control of project implementation and the quality of project results.

Table 1. Phases of the life cycle of the construction project of SK Art-Stroy LLC.

\begin{tabular}{|c|c|c|}
\hline Phase & $\begin{array}{c}\text { Main document under } \\
\text { development }\end{array}$ & Main performer \\
\hline \multirow[t]{3}{*}{ Initiation } & $\begin{array}{l}\text { Declaration (petition), } \\
\text { feasibility study }\end{array}$ & Project Manager of SK Art-Stroy LLC \\
\hline & $\begin{array}{l}\text { Business plan, project charter, } \\
\text { investment feasibility study }\end{array}$ & Project Manager of SK Art-Stroy LLC \\
\hline & Design assignment & Project Manager of SK Art-Stroy LLC \\
\hline \multirow[t]{4}{*}{ Planning } & $\begin{array}{c}\text { Design and estimate } \\
\text { documentation, project } \\
\text { implementation schedule }\end{array}$ & Designer, estimator of SK Art-Stroy LLC \\
\hline & Organization of trades & $\begin{array}{c}\text { Tender Committee of SK Art-Stroy LLC, } \\
\text { applicants }\end{array}$ \\
\hline & $\begin{array}{c}\text { Construction contract, building } \\
\text { permit }\end{array}$ & Customer, contractor \\
\hline & Project of work production & Contractor \\
\hline Implementation & $\begin{array}{l}\text { General work log, matrix of } \\
\text { responsibility, regulations }\end{array}$ & $\begin{array}{l}\text { Designers of "SK Art-Stroy" LLC, } \\
\text { customer, contractor }\end{array}$ \\
\hline \multirow[t]{3}{*}{ Completion } & $\begin{array}{l}\text { Report on the fulfillment of } \\
\text { contractual obligations }\end{array}$ & Project Manager of "SK Art-Stroy LLC" \\
\hline & State Commission Act & All subjects of management \\
\hline & $\begin{array}{l}\text { Object passport, technical } \\
\text { documentation, registration }\end{array}$ & Operating and registration authorities \\
\hline
\end{tabular}

Construction project management of SK Art-Stroy LLC is a very extensive, laborintensive process that includes four stages: initiation, planning, implementation and completion of the project, which in turn consist of a variety of tasks, performers and incoming information. At the end of the analysis of the existing construction project management system of SK Art-Stroy LLC, for clarity, the normal of one of the project 
management stages is presented, with its help it is possible to trace the technologies for performing individual tasks and the relationship of individual officials.

Also, in the course of the analysis, a number of problems were identified that the organization faces in the process of project management, namely:

- violation of terms of the project;

- lack of a highly specialized risk officer;

- qualification of management personnel.

\section{Results}

Let's take a closer look at each of the phases of the life cycle of the construction project of SK Art-Stroy LLC:

1) Project initiation. Any project of SK Art-Stroy LLC begins with the initiation phase, which in turn is carried out in three stages. At the first stage of project initiation, a project concept is developed, within the framework of this concept, investment opportunities are studied, investment goals are determined, an investment concept (idea) is formed, the purpose and capacity of the construction object, the product range, and the approximate location of the planned object are determined.

At the second stage, marketing research is envisaged, and as a result, a declaration (petition) of intentions for the implementation of the project or a task for the development of a justification for investment for the project is developed. This document contains:

1) the basis for the design;

2) type of construction;

3) the name of the investor (or customer) and his address;

4) information about the location, capacity and physical characteristics of the facility;

5) the main parameters of buildings and structures, the timing and sequence of construction;

6) special construction conditions;

7) requirements for engineering systems;

8) requirements for measures to ensure fire safety;

9) design plan;

10) justification of the socio-economic necessity of the planned activity;

11) the need for various resources;

12) transport support;

13) possible impact on the environment;

14) sources of funding;

15) construction time;

16) requirements for the development of estimate documentation;

17) requirements for the composition and content of project documentation.

At the third stage of initiation, a technical and economic assessment of the feasibility of investment justification is carried out.

At the end of this stage, the Charter and the preliminary content of the project are developed.

In SK Art-Stroy LLC, the project charter includes:

1) Purpose and justification of the project - determining the reasons for initiating the project;

2) General description of the project;

3) General budget - the section briefly indicates the results of the express analysis of the project carried out at the stage of project selection;

4) Initial risks - this section specifies typical risks in terms of cost and timing of the project, as well as individual risks inherent in this project; 
5) Acceptance Criteria - determination of the criteria that must be met in order for the project to be accepted by the customer or customer representative;

6) Decisions on personnel - definition of powers;

7) Budget control and changes - the percentage of deviations from budget indicators established on the project is indicated, within which the project manager has the opportunity to make decisions on changes without coordination with the Headquarters and the Board;

8) Technical solutions;

9) Resolution of conflicts.

At the initiation stage, the project team is formed. Project team members report to the Project Manager. The project team is funded from the project budget. The project team includes personnel from the SK Art-Stroy LLC organization itself, as well as, in agreement with the Headquarters, personnel from a third-party organization.

The headquarters is the main body for the operational management of project management activities. The project team is formed by the Project Manager. Each project has its own team.

Forming a project team begins with determining the number and positions of project members in accordance with the scale and nature of the project. After identifying the required specialists, the project manager determines the organizational structure of the project team. Most often, such a structure is superimposed on the one that has already been formed at the enterprise.

Let's represent the project team structure based on the existing organizational structure in Figure 1.

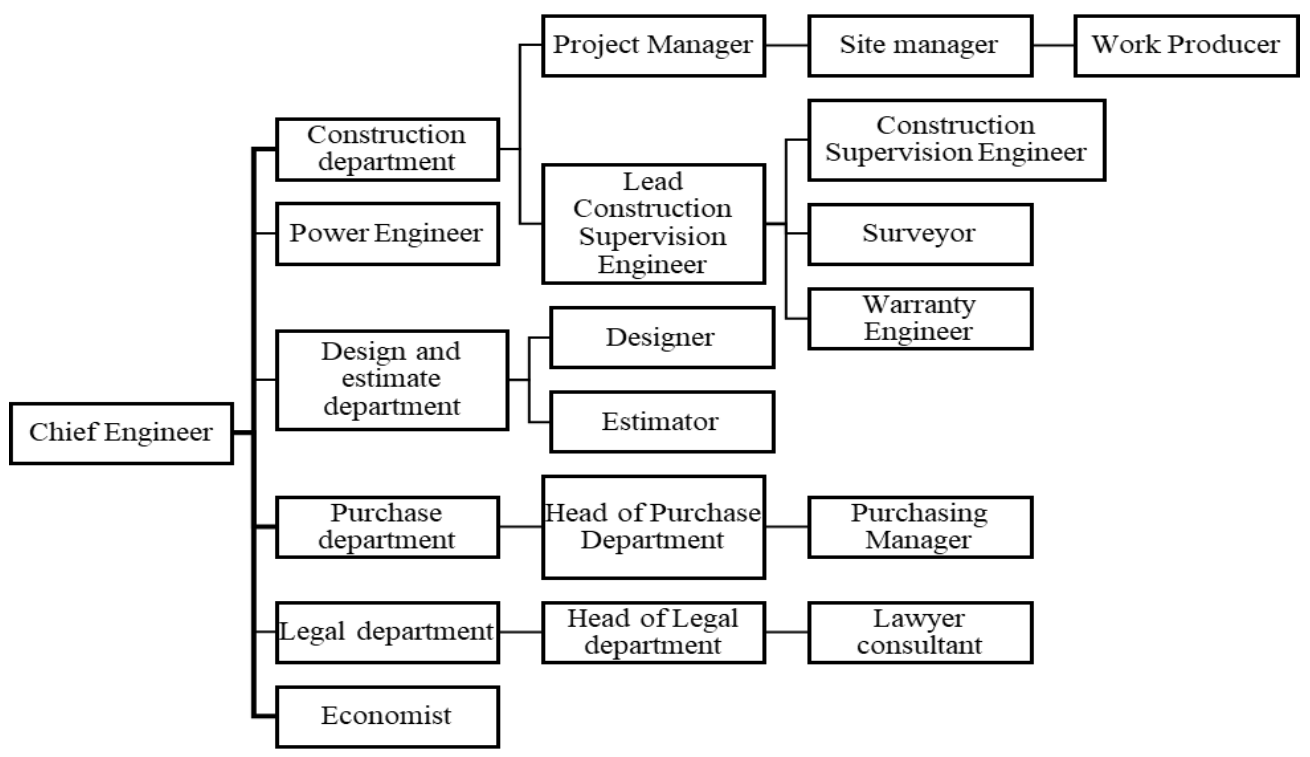

Fig. 1. Structure of the construction project team of SK Art-Stroy LLC.

2) Project planning. If the project, after initiation, goes further into work, then at this stage production schedules are drawn up. At the end, working documents are created indicating the goals, objectives of the project, work, budget and others. The main document at this stage is the project management plan, which, in turn, includes a number of auxiliary plans, on the basis of which the Basic project plan is developed, containing the entire list of project stages, the content of technological operations, start and end dates and performers. The planning process for the construction project of SK Art-Stroy LLC consists of: 
1) Scope Plan — how the scope of the project will be defined, validated, and controlled;

2) Project time management plan - planning, development, management, execution and control over the project deadline;

3) Plan for cost - estimate of monetary resources;

4) Requirements Management Plan - how to analyze, document and manage requirements;

5) Quality management plan - how the quality will be ensured;

6) A communications management plan is the process of developing an appropriate approach and plan for project communications based on the information needs and requirements of stakeholders;

7) Risk management plan - how to manage project risks;

8) Procurement management plan - receiving offers from sellers, selecting sellers and concluding contracts;

9) Stakeholder management plan - identifying people, groups and organizations that may be influenced by the project, or who may be adversely affected. At this stage, a monthly set of activities for weekly planning is being developed.

Thus, the result of this stage is a list of works on the project, while the volume-resource characteristics of the works and their performers are indicated, then the sequence and relationships of the project's work are determined. To do this, SK Art-Stroy LLC uses such a project management tool as a Gantt chart (calendar plan) - this is a horizontal line chart, on which works are depicted as interconnected segments extended in time with start and end dates (Figure 2).

\begin{tabular}{|c|c|c|c|c|c|}
\hline $\begin{array}{r}\text { Time } \\
\text { Types of work }\end{array}$ & 1 & 2 & 3 & 4 & 5 \\
\hline 1 & & & & & \\
\hline $\begin{array}{l}2 \\
3\end{array}$ & & & & & \\
\hline 4 & & & & & \\
\hline 5 & & & & & \\
\hline 6 & & & & & 8 \\
\hline
\end{tabular}

Fig. 2. Gantt chart of SK Art-Stroy LLC.

In addition to production planning, the company develops a plan for holding tenders. The procurement functions are assigned to the tender committee of SK Art-Stroy LLC.

Specialists of the tender committee of SK Art-Stroy LLC draw up a general schedule of the tender, in which they fix the date of the announcement of the tender and the planned date of the tender. All tenders are posted on the official website of SK Art-Stroy LLC in the appropriate section, which indicates the object, period, amount or physical volume. Immediately on the site, one can fill out and send an application for participation in the auction.

3) Execution of the project. In addition to the direct execution of work on the project, at the implementation stage, control is carried out for compliance with planned indicators and actual and quick response to possible problems and deviations. The project manager of SK Art-Stroy LLC can make changes to the schedules in accordance with the changes taking place, force majeure, etc.

Also, at this stage, such project team management tools are used as, regulation and compilation of a matrix of responsibility for each team member, these are simple and understandable tools for understanding the area of responsibility of each project participant. The Responsibility Matrix is a table where the rows contain the tasks of the project, and the 
columns contain the roles of the project participants. The intersection indicates the degree of responsibility of one or another participant for each task. It is a form of description of the distribution of responsibility for the implementation of work on the project, indicating the role of each of the departments in their implementation (table 2).

The roles in the responsibility matrix are assigned as follows:

E - the responsible executor;

$\mathrm{P}$ - the performer;

A - acceptance of works;

C - consultations.

Table 2. Matrix of responsibility of the project participants of SK Art-Stroy LLC.

\begin{tabular}{|c|c|c|c|c|c|}
\hline Tasks & $\begin{array}{c}\text { Chief } \\
\text { Engineer }\end{array}$ & $\begin{array}{c}\text { Project } \\
\text { Manager }\end{array}$ & $\begin{array}{l}\text { Design and } \\
\text { estimate } \\
\text { department }\end{array}$ & $\begin{array}{c}\text { Purchase } \\
\text { department }\end{array}$ & Economist \\
\hline $\begin{array}{l}\text { Appointment of a } \\
\text { project manager }\end{array}$ & $\mathrm{E}$ & & & & \\
\hline $\begin{array}{l}\text { Development of the } \\
\text { project concept }\end{array}$ & $\mathrm{E}$ & $\mathrm{P}$ & & & \\
\hline $\begin{array}{l}\text { Feasibility study of the } \\
\text { project }\end{array}$ & A & $\mathrm{P}$ & $\mathrm{C}$ & & $\mathrm{C}$ \\
\hline $\begin{array}{l}\text { Project assignment, } \\
\text { investment } \\
\text { justification }\end{array}$ & A & E & & & $\mathrm{P}$ \\
\hline $\begin{array}{l}\text { Business plan } \\
\text { development }\end{array}$ & $\mathrm{E}$ & $\mathrm{P}$ & & $\mathrm{C}$ & $\mathrm{C}$ \\
\hline $\begin{array}{l}\text { Development of a } \\
\text { basic project plan }\end{array}$ & A & E & $\mathrm{P}$ & & \\
\hline $\begin{array}{l}\text { Determination of the } \\
\text { composition and } \\
\text { distribution of duties } \\
\text { of performers for work }\end{array}$ & $\mathrm{C}$ & $\mathrm{E}$ & & & \\
\hline $\begin{array}{l}\text { Forming a project } \\
\text { team }\end{array}$ & $\mathrm{A}$ & $\mathrm{E}$ & & & \\
\hline $\begin{array}{l}\text { Development of } \\
\text { design estimates }\end{array}$ & A & & $\mathrm{E}$ & $\mathrm{C}$ & $\mathrm{C}$ \\
\hline $\begin{array}{l}\text { Formation of project } \\
\text { implementation } \\
\text { schedules }\end{array}$ & $\mathrm{A}$ & & $\mathrm{E}$ & & $\mathrm{C}$ \\
\hline Project plan approval & $\mathrm{P}$ & & & & \\
\hline $\begin{array}{l}\text { Supply of resources } \\
\text { for the production of } \\
\text { works }\end{array}$ & & & $\mathrm{C}$ & $\mathrm{E}$ & $\mathrm{C}$ \\
\hline $\begin{array}{l}\text { Organization and } \\
\text { execution of } \\
\text { construction works }\end{array}$ & $\mathrm{A}$ & $\bar{E}$ & $\mathrm{C}$ & & $\mathrm{C}$ \\
\hline $\begin{array}{l}\text { Control over the } \\
\text { progress and quality of } \\
\text { construction work }\end{array}$ & $\mathrm{E}$ & $\mathrm{P}$ & & & \\
\hline $\begin{array}{l}\text { Acceptance of a } \\
\text { construction site } \\
\text { (commissioning) }\end{array}$ & $\mathrm{A}$ & $\mathrm{E}$ & $\mathrm{P}$ & $\mathrm{C}$ & $\mathrm{C}$ \\
\hline $\begin{array}{l}\text { Completion and } \\
\text { evaluation of project } \\
\text { results }\end{array}$ & $\mathrm{A}$ & $\mathrm{E}$ & & & \\
\hline
\end{tabular}


Using this matrix, regulations are developed for the participants in a specific project. As already mentioned above, the weekly and daily work is transferred to the construction site by the planning department employee. At the site, the Project Manager checks the daily plan and fills out draft documents every day. At the end of the month, the signed documents are sent to the planning department, where the actual execution of weekly tasks and the necessary adjustments to the basic work schedule are made using MC Project. Based on data from MC Project, the planner prepares a report for management once a month.

In case of delays, the construction manager, together with the subcontractor, develops an action plan to eliminate the backlog.

Directly at the construction site, work is taking place according to the construction organization project, which includes: cleaning the territory, equipping the construction site, preparing the site for construction, organizing the premises of the Construction Headquarters, organizing sanitary facilities, water supply, electricity, communication and the Internet, lighting, etc. After this stage, contractors and subcontractors enter the construction site and construction begins according to a pre-scheduled plan and weekly and daily planning, observing the construction technology.

The project manager, together with the project team, systematically monitors project costs within the framework of the established workflow and reporting. All changes in costs are estimated in comparison with the preliminary budget of the project and reflected in the monthly report on the progress of the project. In the event of an excess of the project budget, it considers, with the involvement of the necessary specialists, any opportunities to reduce costs by budget items. If this is not possible, then a proposal is developed to increase the sales value of 1 sq. meters for indoor facilities.

The quality control of the project is carried out by the Project Manager and the project management team, and part of the construction and installation work is carried out by the foreman, the technical supervision engineer, the construction manager and the Project Manager. Construction control engineers for each subcontractor control all volumes and quality of work performed.

Communications Control - The process of monitoring and controlling communications throughout the project life cycle to ensure that the information needs of all project stakeholders are met.

The project team monitors risks every month by collecting information on the dynamics of critical risks and the implementation of plans for the implementation of measures for their management, since this task is dealt with by an employee who is not highly specialized in risks, a situation arises of overlooking various kinds of risks, which is also one of the problems of managing a construction projects of "SK Art-Stroy" LLC.

The construction managers and foremen organize the incoming control of materials.

4) Completion of the project. The result is the delivery of the finished building and the preparation of reports and documents on the completion of the project. But it is not tied to the results of the project, and this affects the quality and desire to work. The project team, within the time frame established by the project manager, forms and submits a report on the closure of the project for distribution to the Headquarters members for review. A report and separate attachments to the report are generated.

The project leader, together with the head of the Headquarters, report on the results of the project and defend the report to the Board in a timely manner. All project documentation is given to the archives of SK Art-Stroy LLC.

Following points are critical success factors at the stage of completion of the construction project of SK Art-Stroy LLC:

- working out issues related to planning the acceptance of results;

- active interaction with customers;

- availability of a margin of time for possible modifications during acceptance; 
- all arising problems and controversial issues are resolved before the acceptance procedure is started.

At the end of the analysis of the existing construction project management system of SK Art-Stroy LLC, for clarity, we will draw up the normal of one of the project management stages, with its help it is possible to trace the technologies for performing individual tasks and the relationship of individual officials.

\section{Discussion}

Analysis of the stages and tools for managing the construction project of SK Art-Stroy LLC shows that the project management process in the organization is based on the MCProject software and includes four stages:

1) Project initiation. At this stage, the concept and purpose of the project is determined, an approximate implementation plan is developed, the project charter is developed, a project manager is appointed who forms the project team. The project team of SK Art-Stroy LLC includes: Lead project engineer; project Manager; site manager; work contractor; master of construction and installation works; designer and estimator; Purchasing Manager; tender committee; accountant and economist;

2) Project planning. If the project, after initiation, goes further into work, then at this stage production schedules are drawn up. At the end, working documents are created indicating the goals, objectives of the project, work, budget and others. In addition to production planning, the company develops a plan for holding tenders. The functions of direct procurement are assigned to the tender committee of SK Art-Stroy LLC.

3) Execution of the project. At this stage, there is a direct implementation of what the project was intended for. In addition to the direct execution of work on the project, at the implementation stage, control is carried out for compliance with planned indicators and actual and quick response to possible problems and deviations. SK Art-Stroy LLC can make changes to the schedules in accordance with the changes taking place, force majeure, etc.

4) Completion of the project. The result is the delivery of the finished building and the preparation of reports and documents on the completion of the project.

Construction project management of SK Art-Stroy LLC is a very extensive, laborintensive process that includes four stages: initiation, planning, implementation and completion of the project, which in turn consist of a variety of tasks, performers and incoming information. At the end of the analysis of the existing construction project management system of SK Art-Stroy LLC, for clarity, the normal of one of the project management stages is presented, with its help it is possible to trace the technologies for performing individual tasks and the relationship of individual officials. The study developed the structure of the construction project team and defined the matrix of responsibility of the project participants. Also, in the course of the analysis, a number of problems were identified that the organization faces in the process of project management, namely:

- violation of terms of the project;

- lack of a highly specialized risk officer;

- qualifications of management personnel.

To solve the identified problems, following recommendations were proposed:

- staff remuneration;

- introduction of the position of risk manager;

- advanced training of the management staff. 


\section{Conclusion}

Thus, the results of the study of the stages and tools of construction project management can be used in the work of construction organizations. Implementation of the proposed recommendations will provide the enterprise with a highly qualified staff of specialists, reduce the number and level of risks, increase the efficiency of construction project management and increase the likelihood of projects being completed on time.

\section{References}

1. GOST R 57363-2016 Project management in construction

2. A.M. Afonin, Project Management (Forum, Moscow, 2016)

3. E.K. Verzukh, Project Management: MBA Crash Course (Williams, Moscow, 2015)

4. I.V. Gontareva, Project management (KD Librokom, Moscow, 2018)

5. L.G. Matveeva, Project management (Phoenix, Rostov on Don, 2015)

6. V.N. Ostrovskaya, Project Management Textbook (Saint-Petersburg, Lan, 2018)

7. Yu.S. Perevoshchikov, Project Management in Mechanical Engineering Textbook (Moscow, Infra-M, 2018)

8. O.G. Tikhomirova, Project Management: workshop: Textbook (Moscow, Infra-M, 2016)

9. The official website of the company "SK Art-Stroy" LLC, https://art-stroy.com/

10. Federal State Statistics Service statistical data on the state of the construction industry at different levels, http://www.gks.ru

11. Electronic portal Laws of Russia New town planning code of the Russian Federation (2016) http://www.assessor.ru

12. Electronic portal "Baurum Builder's Guide, http://www.baurum.ru/

13. Humanitarian and legal portal Project Management System, http://psyera.ru

14. V. Lez'Er, N. Semerianova, A. Kopytova, Y. Truntsevsky, E3S Web of Conferences 110, 02093 (2019) DOI: 10.1051/e3sconf/201911002093

15. A.V. Kopytova, N.S. Zotkina, I.G. Reshetnikova, MATEC Web of Conferences 239, 04012 (2018) DOI: 10.1051/matecconf/201823904012

16. V. Lez'Er, N. Semeryanova, A. Kopytova, I. Kvach, E3S Web of Conferences 110, 02094 (2019) DOI: 10.1051/e3sconf/201911002094

17. Y.V. Truntsevsky, I.I. Lukiny, A.V. Sumachev, A.V. Kopytova, MATEC Web of Conferences 170, 01067 (2018) DOI: 10.1051/matecconf/201817001067

18. N. Semeryanova, O. Fedorenko, A. Kopytova, MATEC Web of Conferences 239, 04013 (2018) DOI: 10.1051/matecconf/201823904013 